Ian S. Markham and Joshua Daniel (eds), (2018) Reasonable Radical?: Reading the Writings of Martyn Percy. Eugene, OR: Pickwick. 374 pages, ISBN 978-1-5326-1783-6 (pbk), £31.oo.

Martyn Percy says that he was 'touched - overwhelmed indeed' by the project which culminated in this book. One wonders if he was also a little bemused. It is a rare honour for a living figure still so much in the thick of things to be the subject of a theological conference. The result is an equally unusual book. Three sections consist of new papers, each rounded off by Percy's own response, followed by a selection of his own writings, as well as a few book reviews reproduced for good measure. One of the points made repeatedly is that Percy has written on very diverse topics; that fact is both a feature and a drawback of this book. As with any book based on a conference, many of the contributions are of relatively narrow interest and reflect a geographical selfselection (in this case, largely North American). In the absence of a field called 'Martyn Percy studies' it is hard to see who would be interested in all of them. Percy's own responses are valuable as summaries of his approach, though they struggle to tie together the disparate contributions.

The strongest papers are those which engage critically with Martyn Percy's work and indicate how it can be built on and taken further. Of particular note are the essays by Joel C. Daniels, the late Gerard Mannion, Lyndon Shakespeare and Kathryn D. Blanchard (whose chapter is also the one which most explicitly engages with the other contributions). The first section, on methodology, is inspired by Percy's doctorate, published in 1996 as Words, Wonders and Power. The chapters most likely to be of interest to readers of this journal are Mannion's and Shakespeare's, from the section on ecclesiology. Mannion identifies a trend which he terms 'ecclesiological realism'; he places Martyn Percy in company with Pope Francis and calls for a 'Copernican revolution' which could unseat what he critiques as the top-down idealism of communion ecclesiology. Shakespeare, whilst focusing on pastoral ministry, indicates a way towards squaring this circle, combining Percy's insights with Thomist eucharistic ecclesiology.

A number of contributors contrast Percy's approach with that of the Radical Orthodox, much to the disparagement of the latter. The collection would have benefitted from having a contributor from that school, who might have picked up on the many areas of commonality, not least in Percy's moments of nostalgia for an England that is passing away.

Perhaps unsurprisingly, the most readable and thought-provoking section is the compilation of Percy's own writings. I was grateful that the editors included samples of those writings referred to earlier in the book, though they were 
necessarily too heavily edited to allow a full assessment of the commentary on them. In his opening chapter, Ian Markham highlights the strengths and weaknesses of Percy's style as an 'essayist' (though he fails to note what this owes to the craft of a preacher) and this aspect is well illustrated here. I would concur with Blanchard that Percy is at his best when he engages in exegesis; I will certainly be preaching differently on the Salt of the Earth in future! At the same time, there are many asides and illustrations that seem throwaway, not to say tendentious. A link between obesity and the Scottish referendum is intriguing, but where does it take us? Is it fair to borrow the media characterisation of Justin Welby as 'businessman turned archbishop' and overlook his postordination involvement in conflict resolution? But perhaps this rhetorical looseness of argument is unfairly highlighted here by presenting popular journalistic pieces alongside academic writing for a more specialist audience.

The book as a whole raises some interesting questions, not least whether a Cathedral Dean in the established Church of England can really be a radical Christian - a point made both by Simon Coleman and Kathryn Blanchard. The question may be more whether a radical Christian can be a Dean. To read this book in the light of Percy's recent travails at Christ Church, Oxford, is doubtless both facile and futile, but probably irresistible. The introduction draws attention to his 'sometimes uneasy blend of the irenic and the critical' and there may be an irony in such frequently pungent prose employed in the alleged defence of mildness and moderation. Another question, not explicitly stated, is whether Percy's Cuddesdon 'brand' really represents a neutral 'broad tent' which can hold together differences, or whether (like the secularism which makes similar claims in the public arena) it is one ideological tribe alongside others.

The editors' stated aims are to provide 'a challenge of the academy' in defence of practical theology, and a useful resource for ordinands. As a tool for the working priest, I'm surprised such an approach should even need defending and this collection certainly succeeds in illustrating its usefulness. However, I suspect that readers of this journal would need more convincing of the truth of the assertion that 'ecclesiology is the study of how congregations manifest their theological convictions. There is a risk of falling between two disciplinary stools - how does one make the leap from the anthropology of religion to theology? Is the purpose simply to describe what congregations think about God (a snob or a sceptic might say, How they misunderstand the faith) or to reveal something of what God is actually doing among them? It is important for a priest to be aware, for instance, that a christening will have a multiplicity of meanings for its participants, but what if anything does it change in our sacramental theology of baptism? This collection hints at possible answers, 
referring to liberation theology 'from below' and emphasising Anglican theology as a method more than an outcome: doctrine expressed and elaborated more through practice than propositional argument. This could be fruitfully expanded, perhaps by reference to lex orandi and the parallels with theological development in the Patristic period. Ultimately, this book is more than the sum of its parts. It is awkwardly structured and in parts verges on the hagiographical. Yet if one can get past that, it makes a pitch for an attractive vision of Anglicanism - radically reasonable, if perhaps only reasonably radical.

\section{Katherine Price}

Chaplain, The Queen's College, University of Oxford, Oxford, UK

katherine.price@queens.ox.ac.uk 